Keywords:

Carbonized rice husk

Coconut fiber

Clonal mini-garden

Essential oil

Medicinal plant

Historic:

Received 13/09/2017

Accepted 23/1 1/2017

Palavras chave:

Casca de arroz carbonizada

Fibra de coco

Minijardim clonal

Óleo essencial

Planta medicinal

${ }^{+}$Correspondence: rmonteiro.ef@gmail.com

DOI:
Carlos Andre Stuepp', Rosimeri de Oliveira Fragoso', Pedro Henrique Riboldi Monteiro ${ }^{2+}$, Dagma Kratz², Ivar Wendling ${ }^{3}$, Katia Christina Zuffellato-Ribas ${ }^{2}$

\section{USE OF RENEWABLE SUBSTRATES FOREXVITRO PRODUCTION OF Melaleuca alternifolia CHEEL CLONAL PLANTS BY MINI-CUTTINGS TECHNIQUE}

\begin{abstract}
The Australian species Melaleuca alternifolia Cheel. has a strong commercial importance due to the extraction of essential oils from its leaves used in the cosmetic and pharmaceutical industry. In order to obtain an efficient plant production system of M. alternifolia the mini-cuttings technique and the clonal mini-garden management in the productivity and rooting of mini-cuttings and different substrate compositions were analyzed during all the seasons. Mini-stumps derived from cuttings and grown in pots $(2 \mathrm{~L})$, were submitted to successive harvesting of their sprouts during the four seasons (september/2013 to august/2014). From the mini-stumps sprouts mini-cuttings were produced, wich were were planted in plastic tubes and kept in a greenhouse for 45 days. Six substrates were used for planting the mini-cuttings: commercial substrate (SI); substrate composed of $100 \%$ carbonized rice husk (CRH) (S2); substrate composed of $100 \%$ coconut fiber (CF) (S3); substrate composed of $50 \% \mathrm{CF}$ and $50 \% \mathrm{CRH}$ (S4); substrate composed of $30 \% \mathrm{CF}$ and $70 \% \mathrm{CRH}$ (S5); substrate composed of $70 \% \mathrm{FC}$ and $30 \% \mathrm{CRH}$ (S6). The high survival of mini-stumps (over 90\%) and the mini-cuttings production ( $282 \mathrm{mini}$-cuttings $\left.\cdot \mathrm{m}^{-2} \cdot \mathrm{month}^{-1}\right)$ in the shade house demonstrate the technical feasibility for the species, being summer the most appropriate time to collect propagules. The substrate composed by $70 \% \mathrm{CF}+30 \% \mathrm{CRH}$ (S6) shows superior results for vegetative propagation of $M$. alternifolia $(91.7 \%$ of rooted mini-cuttings), as the single one to contemplate simultaneously all parameters. Summer is recommended as the best time for rooting of mini-cuttings.
\end{abstract}

\section{SUBSTRATOS RENOVÁVEIS NA PRODUÇÃO EX VITRO DE MUDAS DE Melaleuca alternifolia CHEEL. POR miniestaquia}

RESUMO: A espécie australiana Melaleuca alternifolia Cheel., tem uma forte importância na indústria farmacêutica e de cosméticos devido a extração dos óleos essenciais presentes nas folhas. Visando um sistema eficiente de produção de mudas de $M$. alternifolia, avaliou-se a técnica de miniestaquia e manejo do minijardim clonal na produtividade e enraizamento de miniestacas, além das diferentes composições de substratos nas quatro estações do ano. Minicepas provenientes de mudas propagadas por estaquia foram analisadas durante as quatro estações do ano (setembro/20I3 a agosto/20I4). A partir das brotações das minicepas foram produzidas miniestacas, as quais foram plantadas em tubetes e mantidas em casa de vegetação por 45 dias. Foram seis os substratos utilizados para o plantio das miniestacas: substrato comercial (SI); substrato composto por 100\% de casca de arroz carbonizada (CRH) (S2); substrato composto por $100 \%$ de fibra de coco (CF) (S3); substrato composto por $50 \%$ CF e $50 \%$ CRH (S4); substrato composto por $30 \%$ CF e $70 \%$ CRH (S5); substrato composto por $70 \%$ CF e $30 \%$ CRH (S6). A elevada sobrevivência das minicepas (superior a $90 \%$ ) e produção de miniestacas (282 miniestacas. $\mathrm{m}^{-2}$.mês) em casa de sombra demonstram a viabilidade da técnica para a espécie, sendo o verão a época mais adequada para coleta de propágulos. O substrato a base de $70 \% \mathrm{CF}+30 \% \mathrm{CRH}(\mathrm{S} 6)$ apresenta resultados superiores para a propagação vegetativa de $M$. alternifolia ( $91,7 \%$ de estacas enraizadas), sendo o único a atender simultaneamente todos os parâmetros avaliados. Recomenda-se o verão como a melhor época para enraizamento das miniestacas.

' State University of Ponta Grossa - Ponta Grossa, Paraná, Brazil

${ }^{2}$ Federal University of Paraná - Curitiba, Paraná, Brazil

${ }^{3}$ Embrapa Florestas-Colombo, Paraná, Brazil 


\section{INTRODUCTION}

Melaleuca alternifolia Cheel. (Myrtaceae), also known as malaleuca, crops up naturally in Australia, where it is widely cultivated and exported to North America and Europe, being used in cosmetics and the pharmaceutical industry (WONGA et al., 2015). Its commercial importance is due to the extraction of the essential oils of its leaves, which have components such as terpinene, gamma-terpinene, alpha-terpinene and cineole.

Even been possible its propagation by seedlings, the reduced size of $M$. alternifolia seeds and the great genetic variability make this method of propagation disadvantageous (OLIVEIRA et al., 20I0).

Several studies have evaluated the propagation of $M$. alternifolia in different substrates, plant growth regulators and types of mini-cuttings (OLIVEIRA et al., 2012a; SILVA et al., 20I2b; STUEPP et al., 20I3). However, there's no system capable of producing $M$. alternifolia high genetic quality plants at any time of the year.

The mini-cuttings technique has shown satisfactory results for many species in the production of genetically superior clones (BRONDANI et al., 2012; KRATZ et al., 20I5; STUEPP et al., 2015.). Its main advantage is a higher productivity of plants with high percentages of roots without the need of plant growth regulators (BRONDANI et al., 2010; WENDLING et al., 2010).

In addition to the physiological quality of the material, the substrate used has a key role on the rhizogenic capacity of cuttings. Aspects such as availability of water and oxygen, density, porosity and $\mathrm{pH}$ are essential to the development of the roots (KRATZ et al., 2013; KRATZ et al., 20I5.). The use of established substrates such as peat (plant) and vermiculite (mineral) (SCHMITZ and KÄMPF, 2002), being both non-renewable, have increasingly been hindered by the high environmental impact of their extraction (CALDEIRA et al. 20I I), thus favoring the pursuit of renewable components. The materials available on the market include carbonized rice husk and coir. Besides the reduced environmental impact and cost, both stand out for their important physical and chemical properties on plant propagation (KRATZ et al., 20I2; SILVA et al., 20I2a).

Given the importance of developing an efficient production system of $M$. alternifolia plants, the technical feasibility of mini-cuttings technique, the management of clonal mini-garden productivity and rooting cuttings were considered, whilst different compositions of substrates in different seasons were evaluated.

\section{MATERIAL AND METHODS}

The experiments were conducted from may/20 I 3 to august/20I4 in Curitiba (PR), Brazil (25 44' S and $49^{\circ}$ 23' W, $920 \mathrm{~m})$. According to Köppen's classification,
Curitiba is classified as "Cfb" which states that its climate is temperate with the temperature of its coldest month at between -3 and $18{ }^{\circ} \mathrm{C}$. It is always wet with welldistributed rain throughout the year and the average temperature of the warmest month being below $22^{\circ} \mathrm{C}$.

The M. alternifolia clonal mini-garden formed of clonal plants produced from cuttings (STUEPP et al., 2013) was conducted in a shade house (50\% irradiation) in 2 litres pots with coconut fiber and peat based commercial substrate, with a $20 \times 20 \mathrm{~cm}\left(25\right.$ mini-stumps. $\left.\mathrm{m}^{-2}\right)$ spacing, periodical irradiation (micro sprinkling three times a day for 10 minutes and a I44 L.hora ${ }^{-1}$ flow) and weekly fertigation $(25 \mathrm{~mL}$ of nutritional solution consisting of: $4 \mathrm{~g} \cdot \mathrm{L}^{-1}$ of ammonium sulfate, triple superphosphate, potassium chloride and I $g \cdot L^{-1}$ of FTE BR-I2).

To wait for the standardization of the sprouts, the first mini-stumps pruning was 90 days after the adaptation period of the plants. It has been done 10 $\mathrm{cm}$ above the collar stem. Taking considerable care to ensure that there were still at least a couple of buddings. (Figure IA). After that, the buddings harvest happened every 30 days period with three harvests each season, being then 12 harvests in 12 months in total. The cuttings selected were only the ones higher than $10 \mathrm{~cm}$. Cuttings that were out of the stated pattern were kept in ministumps to be only harvested afterward.
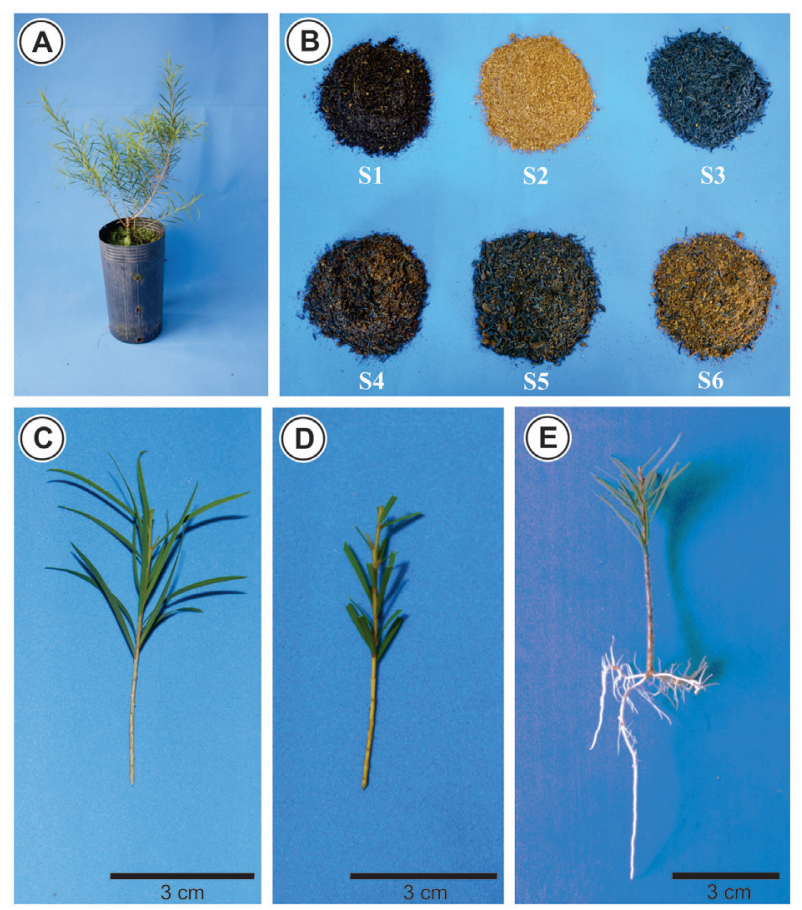

FIGURE I Schematic sequence of $M$. alternifolia's minicuttings: mini-stump $(A)$, substrates $(B)$, minicuttings made of leaves $(C)$, mini-stump made with a $50 \%$ reduction in the leaf area (D) and minicuttings evaluated 45 days after its installation (E). 
The cuttings were made with $6 \pm 1 \mathrm{~cm}$ long and an average diameter of $0.1 \pm 0.1 \mathrm{~cm}$, with bevelled cuts on the basis and straight cuts above the last bud. In the end, keeping $50 \%$ of the leaves reduced to a third of its original surface (Figure IC, D). The planting was in $55 \mathrm{~cm}^{3}$ tubes-filled with the evaluated substrates and kept in a greenhouse with intermittent misting (temperature: $24^{\circ} \mathrm{C}$ $\pm 2{ }^{\circ} \mathrm{C}$; air humidity: higher than $80 \%$ ).

In this experiment six substrates were evaluated: a pine bark and coconut fiber based commercial substrate (SI); a 100\% carbonized rice husk substrate (CRH) (S2); a $100 \%$ mixed coconut fiber (CF) (fibrous and granular) (S3); a 50\% coconut fiber (CF) and $50 \%$ carbonized rice husk substrate (CRH) (S4); a 30\% coconut fiber (CF) and $70 \%$ carbonized rice husk substrate $(\mathrm{CRH})(\mathrm{S} 6)$.

Except for the commercial substrate, all substrates were prepared manually. Physical and chemical characterization of the substrates were applied according to the methodology described in the Normative Instruction No. 17 of the Ministry of Agriculture, Livestock and Supply (MAPA, 2007) (Table I).

The mini-garden evaluations occurred from september/20I3 to august $/ 2014$, throughout the four seasons. The mini-stumps survival percentage (MSP), production of mini-cuttings. $\mathrm{m}^{-2} \cdot$ month $^{-1}$ (PM) and production of mini-cuttings.mini-stumps ${ }^{-1}$ (PMM) were evaluated. The experimental design was completely randomized, in a split-plot model, with five replications of ten mini-stumps per experimental unit.

The mini-cuttings were evaluated 45 days after their installation. Being assessed: the rooting percentage (mini-stumps that were at least I mm long); number of roots.mini-stumps ${ }^{-1}$; length of the three biggest roots.ministumps $^{-1}(\mathrm{~cm})$; survival percentage (mini-stumps that were alive and had no root induction nor calluses formation); mortality rate (mini-cuttings that were found with necrotic tissues); percentage of emission of new shoots; percentage of leaf maintenance (mini-cuttings that maintained at least one original leaf). The experimental design was completely randomized, with factorial arrangement $4 \times 6$ (4 seasons of the year $\times 6$ substrates), with four replications of 12 minicuttings per experimental unit.
From the variables assessed, the multiplication rate (MR) of mini-cuttings. $\mathrm{m}^{-2} \cdot$ month $^{-1}$, according to methodology described in Wendling et al. (20I5).

$M R=P M\left(m^{2} \cdot m o n t h^{-1}\right) \cdot$ Rooting $(\%)$

All data has been assessed for its homogeneity through Bartlett's test, and the means compared according to Tukey's test at a $5 \%$ probability level.

\section{RESULTS AND DISCUSSION}

The rate of mini-stumps survival remained high (over $90 \%$ ) throughout the four seasons of the year (Figure 2A). This result reflects on the adaptability of the material to the environmental and nutritional conditions provided in the shade house and evidences the maintenance of the mini-stumps vigor throughout the experimental period (12 months). A slight reduction in survival is observed in the winter, possibly related to the longer maintenance period of the mini-stumps (the last season to be evaluated) and less favorable weather conditions of that season. Short days associated with low temperatures wield a negative effect on the plant's translocation processes and photosynthesis due to the inhibition of the phosphate input in chloroplasts (Lawson et al., 2012), causing the highest stress level on ministumps undergoing continuous harvesting.

Regarding the mini garden's productivity, the highest values for the production of mini-cuttings $\cdot \mathrm{m}^{-2}$. month $^{-1}$ (PM) and production of mini-cuttings.ministumps $^{-1}$ (PMM) were verified during summer and spring (Figure 2B, C). In warm seasons, the plants species are in full vegetative growth, with the emission of buds and young leaves and, therefore, they present the best balance between nutrient uptake and sprout recovering (BRONDANI et al., 20I0; STUEPP et al. 20I5). Further studies have also reported higher productivity of ministumps in high temperature (FERRIANI et al., 20II; PIRES et al., 2015). These results are greater than those obtained on other species (WENDLING et al., 2007; DIAS et al., 20I2), however, it is necessary to consider the influence of distinct systems.

TABLE I Physical and chemical characterization of the substrates used on the M. alternifolia mini-cuttings.

\begin{tabular}{lcccccccc}
\hline \multirow{2}{*}{ Substrate } & $\mathrm{pH}$ & $\mathrm{EC}$ & $\mathrm{AD}$ & $\mathrm{TSSC}$ & $\mathrm{TP}$ & Macro & Micro & EAW \\
\cline { 2 - 8 } & $\mathrm{H}, \mathrm{O}$ & $\mathrm{mS} \cdot \mathrm{cm}^{-1}$ & $\mathrm{Kg} \cdot \mathrm{m}^{-3}$ & $\mathrm{~g} \cdot \mathrm{L}^{-1}$ & & $---\%$ & --- & \\
\hline SI - Comercial substrate & 4.20 & 1.26 & 198.0 & 1.56 & 80.37 & 10.29 & 70.08 & 31.04 \\
S2 - CF (I00\%) & 5.25 & 0.35 & 81.02 & 0.13 & 82.08 & 21.95 & 60.13 & 27.09 \\
S3 - CRH (I00\%) & 7.36 & 0.08 & 102.9 & 0.04 & 81.70 & 64.30 & 17.39 & 7.25 \\
S4 - CF (50\%) + CRH (50\%) & 4.91 & 0.75 & 109.4 & 0.42 & 81.02 & 27.88 & 53.14 & 29.63 \\
S5 - CF (30\%) + CRH (70\%) & 5.21 & 0.49 & 122.4 & 0.29 & 80.38 & 41.27 & 39.11 & 20.75 \\
S6 - CF (70\%) + CRH (30\%) & 5.72 & 0.26 & 90.43 & 0.11 & 82.29 & 36.05 & 46.24 & 19.90 \\
\hline
\end{tabular}

$\mathrm{pH}=$ determined by water, dilution I:5 (v/v); EC = electrical conductivity obtained in the solution I:5 (v/v); AD = apparent density; TSSC = total soluble salts content; $\mathrm{TP}=$ total porosity; Macro = macroporosity; Micro = microporosity; EAW = easily available water. 

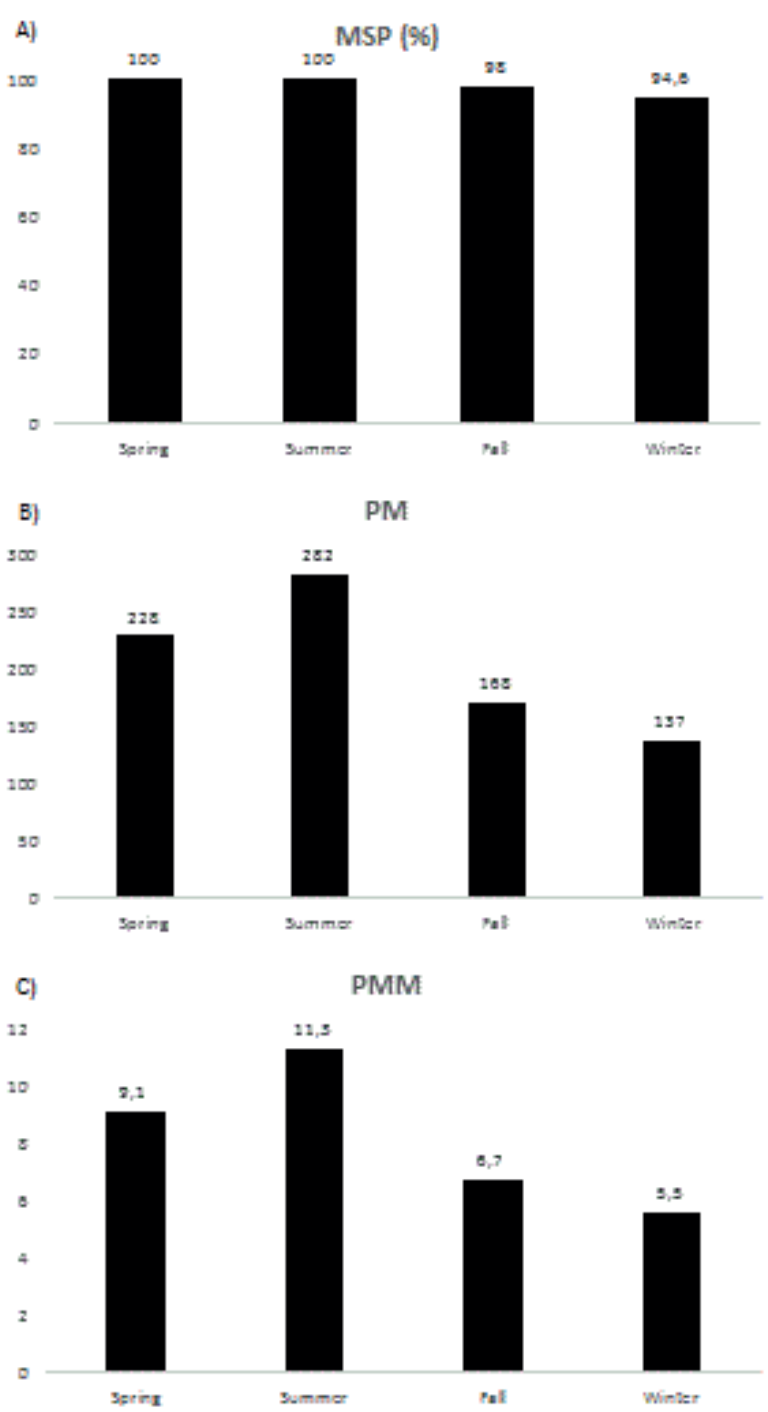

FIGURE 2 General means of variables, percent survival ministumpss (MSP) (A) cuttings. $\mathrm{m}^{-2} \cdot$ month $^{-1}$ (PM) (B) and production of mini-cuttings $\cdot$ mini-stumps ${ }^{-1}(\mathrm{PMM})(\mathrm{C})$ clonal mini-garden $M$. alternifolia, depending on the seasons. Means followed by the same letter do not differ according to Tukey's test at $5 \%$ probability.

Regarding mini-cuttings, although the results show a certain variation on which may be the best substrate or season, it is generally observed that the highest percentages of rooting, shoot formation and leaf maintenance were obtained in the summer and for substrates S2 (100\% CF) and S6 (70\% CF + 30\% CRH) (Table 2). As it is often observed in many species, the results show the straight relationship between these variables, demonstrating the importance of buds and leaves in the supply of essential metabolites to the rooting process (RUEDELL et al., 20I3; FRAGOSO et al., 20I5).

These results indicate the viability of the minicuttings technique on $M$. alternifolia rooting, with greater results $(91.7 \%)$ than those achieved in other researches which used adult propagules (12.3\% to $52.5 \%$ ) (OLIVEIRA et al., 20I2b; SILVA et al., 20I2b; STUEPP et al., 2013). It has also shown better results in comparison with the study that used cuttings from epicormic shoots (18.0\% to $74.0 \%)$, a material with greater juvenility collated to the shoots of that year. The authors assessed different substrates for the $M$. alternifolia rooting, nevertheless, it is noteworthy that the highest percentage obtained (of $74 \%$ ) was attained using a coconut fiber substrate product. The authors point out that coconut fiber possibly provided the best rooting bed because it can offer a higher porosity and water retention, akin to what has been observed on this paper's research.

For an ideal substrate, however, it is important to keep in mind that not only the formation of roots should be taken into account, but also their appliance for producing plants. A good substrate should have good propagation support, equilibrium in water retention and oxygen supply (HOFFMANN et al., 1996).

Regarding total porosity (Table I), all substrates encompass the recommended amount of $75-85 \%$ (MAEDA et al., 2007). However, the increase in the percentage of coconut fiber added to carbonized rice hull (above 50\%) increased its total porosity because of its higher amount of micropores, making S6 the appropriate substrate that complies with all the requirements established and evaluated. Only a bulk density showed a lower percentage $\left(90 \mathrm{~kg} \cdot \mathrm{m}^{-3}\right)$ than the one recommended of $100 \mathrm{~kg} \cdot \mathrm{m}^{-3}$ and $300 \mathrm{~kg} \cdot \mathrm{m}^{-3}$ (KÄMPF, 2005).

We could noticed that coconut fiber (S2) and carbonized rice husk (S3) as pure components unredeemed the percentages of macro and micropores needed. The good performance of the combination of these materials is possibly related to the great water retention promoted by the coconut fiber, in balance with the excellent drainage favored by the carbonized rice husk (SILVA et al., 2012a).

Some papers emphasize that the addition of coconut fiber to other materials is an important resource for a better substrate physical structuring due to its efficient root-aggregation (CARRIJO et al., 2002). In addition, increasing the amount of available water, which should be between 20\% and 30\% (CADAHIA, 1998), promotes the development of the species, since $M$. alternifolia (native to marshes and close to rivers) has affinity to moist environments (LEE et al., 2002).

Because of the chemical characteristics, it is recommended to use mineral materials with $\mathrm{pH}$ between 
TABLE 2 Average of rooting percentage, shoot emission, leaf maintenance, survival and mortality, number of roots $\cdot$ mini-cuttings $^{-1}$ and length of the three major roots-mini-cuttings ${ }^{-1}$ in mini-cuttings of $M$. alternifolia from clonal mini-garden, planted in different substrates and seasons $I$.

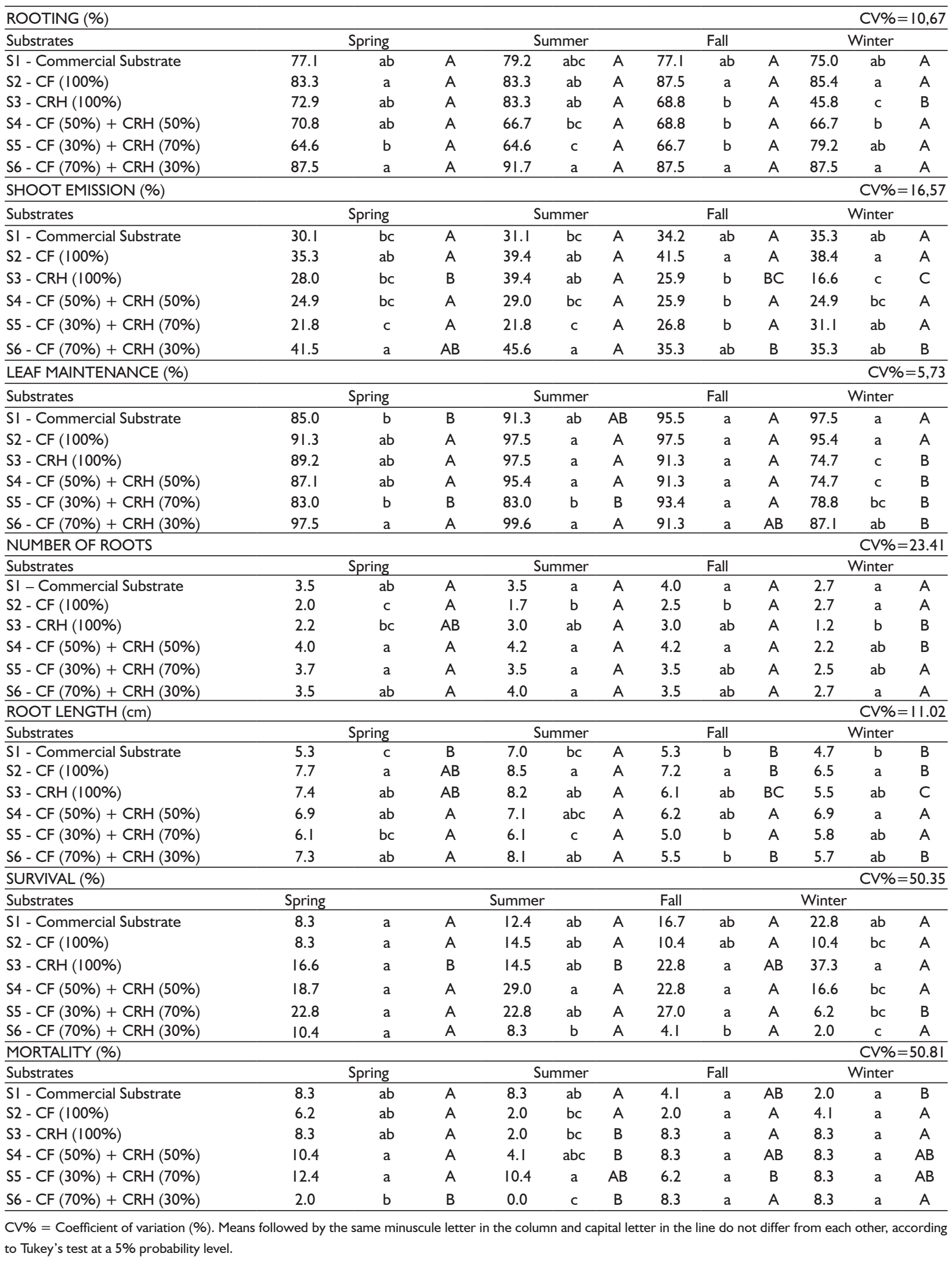


5.5 and 6.5 (KRATZ et al., 20I3, KRATZ et al., 20I5), electrical conductivity (EC) below $1.0 \mathrm{mS} \cdot \mathrm{cm}^{-1}$ (STEUPP et al., 2016) and the total soluble salts content (TSSC) between $0.0 \mathrm{~g} \cdot \mathrm{L}^{-1}$ and $0.5 \mathrm{~g} \cdot \mathrm{L}^{-1}$ (CONOVER, 1967). The substrate SI (Commercial Substrate) was the one that deviated the most from all characteristics above.

$\mathrm{PH}$ values outside the recommended range have a great influence on plant growth because $\mathrm{pH}$ interferes with nutrient availability and may reduce root development (WEBER-BLASCHKE et al., 2008). Similarly, high values of EC and salinity can damage roots and root hair, requiring a higher energy expenditure of the plant to absorb water, affecting essential metabolic processes (BRANDÃO and LIMA, 2002).

Regarding the root strength, the substrates presented, in general, approximate values (Table 2). There was only a small reduction of them in the substrates S2 and S3 referring to the number of roots and in the substrates $\mathrm{SI}$ and $\mathrm{S} 5$ connected to the length of the roots. These results seem to be related to the apparent density of the substrates, since this characteristic has important influence on the process of root formation. Substrates below the recommended values cannot handle the plant's needs, which would justify the lower number of roots (1.7) obtained from the lower density substrate (S2) $\left(81.02 \mathrm{Kg} \cdot \mathrm{m}^{-3}\right)$ and at the same time, the largest root length $(8.5 \mathrm{~cm})$, due to the lower mechanical impedance (DE BOODT and VERDONCK, 1972) and possibly the need for better fixation of the few roots formed. Considering the seasons of the year, although there was not much variation of the results, it was observed a lower plasticity of substrates S3 and S4 with a reduction in the number of roots in the winter period. As for the root length variable, only the substrates S4 and S5 did not show reduced values during colder temperatures.

Regarding survival and mortality variables values were generally low - less than $30 \%$ for survival and less than $10 \%$ for mortality - for all substrates and stations evaluated (Table 2 ). The reduced mortality rate again demonstrates the technical efficiency of mini-cuttings for the production of $M$. alternifolia clonal plants and, at the same time, demonstrates the good nutritional management of the mini-stumps.

As expected, the highest multiplication rates were verified for the substrate S6 (Figure 3). The warmer seasons favored higher productivity of mini-cuttings with the best results obtained in the summer ( 258.5 plants $\cdot \mathrm{m}^{-2}$. month-1). The high multiplication rate of $M$. alternifolia by mini-cuttings is highly desirable, mainly because it results in the production of high-quality clonal plants and easy acclimatization after rooting.

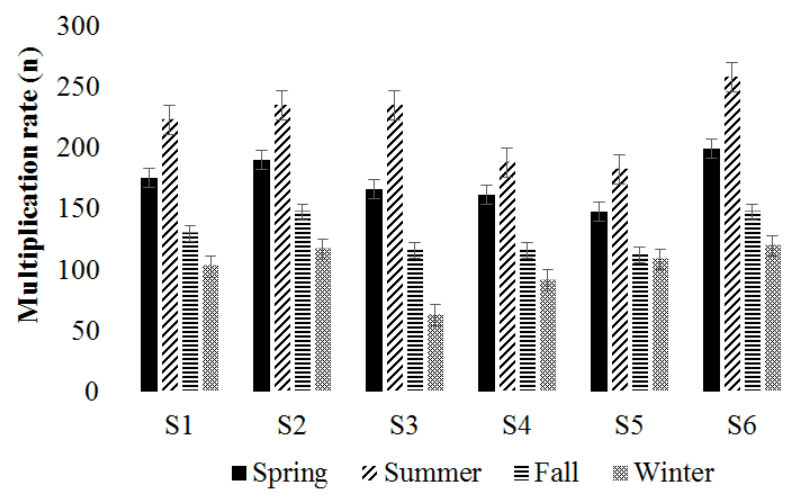

FIGURE 3 Multiplication rate (MR) of mini-cuttings of $M$. alternifolia from clonal mini-garden, planted on different substrates and seasons. SI (commercial substrate); S2 (100\% carbonized rice husk); S3 ( $100 \%$ coconut fiber); S4 (50\% carbonized rice husk $+50 \%$ coconut fiber); S5 (70\% carbonized rice husk $+30 \%$ coconut fiber) and S6 (30\% carbonizedrice husk $+70 \%$ coconut fiber).

\section{CONCLUSION}

The high survival of the mini-stumps production and survival of mini-cuttings in greenhouses show the viability of the mini-cuttings technique for the species, being the summer the best season for collection of propagules. The substrate based on $70 \% \mathrm{CF}+$ $30 \% \mathrm{CRH}$ (S6) presents superior results for the vegetative propagation of $M$. alternifolia, being the only one that simultaneously complies with all the requirements established and evaluated. Although the results do not always reveal a significant difference between the seasons, summer is recommended as the best time for rooting mini-cuttings.

\section{REFERENCES}

BRANDÃO, S. L.; LIMA, S. C. pH e condutividade elétrica em solução do solo, em áreas de pinus e cerrado na Chapada, em Uberlândia (MG). Caminhos de Geografia, v. 3, n. 6, p. 46-56, 2002.

BRONDANI, G. E., GROSSI, F; WENDLING, I.; DUTRA, L. F; ARAUJO, M. A. IBA application for rooting of Eucalyptus benthamii Maiden and Cambage $x$ Eucalyptus dunnii Maiden mini-cuttings. Acta Scientiarum. Agronomy, v. 32, n. 4, p. $667-674,2010$.

BRONDANI, G. E.; WENDLING, I.; BRONDANI, A. E.; ARAUJO, M. A.; SILVA, A. L. L. D.; GONÇALVES, A. $N$. Dynamics of adventitious rooting in mini-cuttings of Eucalyptus benthamii $x$ Eucalyptus dunnii. Acta Scientiarum. Agronomy, v. 34, n. 2, p. 169-178, 2012.

CADAHIA, C. Fertirrigacion: cultivos hortícolas y ornamentales. Madrid: Mundi-Prensa, 1998. 475p. 
CALDEIRA, M. V. W.; WENDLING, I.; PENCHEL, R. M.; GONÇALVES, E. O.; KRATZ, D.; TRAZZI, P.A. Propriedades de substratos para produção de mudas florestais. In: CALDEIRA, M. V. W. et al. (Ed.). Contexto e Perspectivas da Área Florestal no Brasil. Alegre: Suprema, 20II. p. 14I-160.

CARRIJO, O. A.; LIZ, R. S.; MAKISHIMA, N. Fibra de casca de coco verde como substrato agrícola. Horticultura Brasileira, v. 20, n. 4, p. 533-535, 2002.

CONOVER, S. A. Soil mixes for ornamental plants. Florida Flowers Grower, v. 4, n. 4, p. I-4, 1967.

DE BOODT, M.; VERDONCK, O. The physical properties of the substrates in: Floriculture. Acta Horticulturae, v. 26, n. I, p. 37-44, 1972.

DIAS, P. C.; OLIVEIRA, L. S.; XAVIER, A.; WENDLING, I. Estaquia e miniestaquia de espécies florestais lenhosas do Brasil. Pesquisa Florestal Brasileira, v. 32, n. 72, p. 453462, 2012.

FERRIANI, A. P.; ZUFFELLATO-RIBAS, K. C.; HELM, C. V.; BOZA, A.; WENDLING, I.; KOEHLER, H. S. Produção de brotações e enraizamento de miniestacas de Piptocarpha angustifolia. Pesquisa Florestal Brasileira, v. 3I, n. 67, p. 257-264, $201 \mathrm{I}$.

FRAGOSO, R. O.; MARQUES WITT, N. G. D. P.; VANI OBRZUT, V.; VALÉRIO, S.; ZUFFELLATO-RIBAS, K. C.; STUEPP, C. A. Maintenance of leaves and indolebutyric acid in rooting of juvenile Japanese Flowering Cherry cuttings. Revista Brasileira de Ciências Agrárias, v. I0, p. 97-101, 2015.

KRATZ, D.; WENDLING, I.; PIRES, P. P. Miniestaquia de Eucalyptus benthamii $\times E$. dunnii em substratos a base de casca de arroz carbonizada. Scientia Forestalis, v. 40, n. 96, p. 547-556, 2012.

KRATZ, D.; WENDLING, I.; NOGUEIRA, A. C.; DE SOUZA, P. V. Propriedades físicas e químicas de substratos renováveis. Revista Árvore, v. 37, n. 6, p. II03-1।13, 2013.

KRATZ, D.; WENDLING, I.; PIRES, P. P.; STUEPP, C. A. Produção de mudas de erva-mate por miniestaquia em substratos renováveis. Revista Floresta, v. 45, n. 3, p. $609-616,2015$.

LAWSON, T.; KRAMER, D. M.; RAINES, C. A. Improving yield by exploiting mechanisms underlying natural variation of photosynthesis. Current Opinion in Biotechnology, v. 23, n. 2; p. 2I5-220, 2012.

LEE, L. S.; BROOKS, L. O.; HOMER, L. E.; ROSSETTO, M.; HENRY, R. J.; BAVERSTOCK, P. R. Geographic variation in the essential oils and morphology of natural populations of Melaleuca alternifolia (Myrtaceae). Biochemical Systematics and Ecology, v. 30, n. 4, p. 343-360, 2002.

MAEDA, S.; DEDECEK, R. A.; AGOSTINI, R. B.; ANDRADE, G. C.; SILVA, H. D. Caracterização de substratos para produção de mudas de espécies florestais elaborados a partir de resíduos orgânicos. Pesquisa Florestal Brasileira, n. 54, p. 97-104, 2007.
MAPA - MINISTÉRIO DA AGRICULTURA, PECUÁRIA E ABASTECIMENTO. Instrução Normativa SDA N 17. Diário Oficial da União- Seção I, n 99, 24 de maio de 2007. Métodos Analíticos Oficiais para Análise de Substratos para Plantas e Condicionadores de Solo. Brasília, 2007.

OLIVEIRA, A. C. M.; FONTANA, A.; NEGRINI, T. C.; NOGUEIRA, M. N. M.; ANDRADE, C. R.; SPOLIDORIO, L. C.; SPOLIDORIO, D. M. P. Emprego do óleo de Melaleuca alternifolia Cheel (Myrtaceae) na odontologia: perspectivas quanto à utilização como antimicrobiano alternativo às doenças infecciosas de origem bucal. Revista brasileira de plantas medicinais, v. I3, n. 4, p. 492-499, 201 I.

OLIVEIRA, Y.; PINTO, F.; da SILVA, A. L. L.; GUEDES, I.; BIASI, L. A.; QUOIRIN, M. An efficient protocol for micropropagation of Melaleuca alternifolia Cheel. In Vitro Cellular \& Developmental Biology - Plant, v. 46, n. 2, p. 192-197, 2010.

OLIVEIRA, Y.; ALCANTARA, G. B.; GUEDES, I.; PINTO, F.; QUOIRIN, M.; BIASI, L. A. Substrates, indolebutyric acid levels and types of mini-cuttings on the rooting of tea tree (Melaleuca alternifolia Cheel). Revista Brasileira de Plantas Medicinais, v. 14, n. 4, p. 6II-6I6, $2012 a$.

OLIVEIRA, Y.; LOPES, V.; SOUZA, S.; ZUFFELLATO-RIBAS, K. C.; NERY, F.; KEPPEN, S. Influência do ácido indol butírico e de diferentes alturas de coleta de estacas apicais no enraizamento de Melaleuca alternifolia [maiden \& betche] cheel. Revista Brasileira de Agrociência, v. 18, n. 2-4, p. 196-203, 20I2b.

PIRES, P.; WENDLING, I.; AUER, C.; BRONDANI, G. Sazonalidade e soluções nutritivas na miniestaquia de Araucaria angustifolia (Bertol.) Kuntze. Revista Arvore, v. 39, n. 2, p. 283-293, 2015.

RUEDELL, C. M.; ALMEIDA, M. R.; SCHWAMBACH, J.; POSENATO, C. F; FETT-NETO, A. G. Pre and postseverance effects of light quality on carbohydrate dynamics and microcutting adventitious rooting of two Eucalyptus species of contrasting recalcitrance. Plant Growth Regulation, v. 69, n. 3, p. 235-245, 2013.

SCHMITZ, J. A. K; KÄMPF, A. N. Propriedades químicas e físicas de substratos de origem mineral e orgânica para o cultivo de mudas em recipientes. Ciência Rural, v. 32, n. 6. p. 937-944, 2002.

SILVA, R. B. G.; SIMÕES, D.; SILVA, M. R. Qualidade de mudas clonais de Eucalyptus urophylla $\times E$. grandis em função do substrato. Revista Brasileira de Engenharia Agrícola e Ambiental, v. 16, n. 3, p. 297-302, 2012 a.

SILVA, R.; ANTUNES, M.; ROVEDA, L.; CARVALHO, T.; BIASI, L. Enraizamento de estacas de Melaleuca alternifolia submetidas a diferentes reguladores vegetais. Semina, v. 33, n. 5, p. 1643-1652, 2012 b.

STUEPP, C. A.; PEREIRA, G.P.; ZEM, L. M.; PEÑA, M. L. P.; BUENO, P. M. C.; SPADER, V.; ZUFFELLATO-RIBAS, K. C.; ROSA, G. M. Enraizamento de melaleuca: influência da altura de coleta das estacas e aplicação de IBA. Colloquium Agrariae, v. 9, n. I, p. 0I-09, 2013. 
STUEPP, C. A.; ZUFFELLATO-RIBAS, K. C.; KOEHLER, H. S.; WENDLING, I. Rooting mini-cuttings of Paulownia fortune var. mikado derived from clonal mini-garden. Revista Árvore, v. 39, n. 3, p. 497-504, 2015.

STUEPP, C. A.; WENDLING, I.; KOEHLER, H. S.; ZUFFELLATO-RIBAS, K. C. Quality of clonal plants of Piptocarpha angustifolia in different renewable substrates and seasons of the year. Pesquisa Agropecuária Brasileira, v. 5I, n. II, p. I82I-I829, 2016.

WEBER-BLASCHKE, G.; CLAUS, M.; REHFUESS, K. E. Growth and nutrition of ash (Fraxinus excelsior L.) and sycamore (Acer pseudoplatanus L.) on soils of different base saturation in pot experiments. Forest Ecology and Management, v. I67, p. 43-56, 2002.

WENDLING, I.; BRONDANI, G. E.; DUTRA, L. F.; HANSEL, F. A. Mini-cuttings technique: a new ex vitro method for clonal propagation of sweetgum. New Forests, v. 39, p. 343-353, 2010.
WENDLING, I.; BROOKS, P. R.; TRUEMAN, S. J. Topophysis in Corymbia torelliana $\mathrm{x} C$. citriodora seedlings: adventitious rooting capacity, stem anatomy, and auxin and abscisic acid concentrations. New Forests, v. 46, n. I, p. 107-I20, 2015.

WENDLING, I.; DUTRA, L. F; GROSSI, F. Produção e sobrevivência de miniestacas e minicepas de ervamate cultivadas em sistema semi-hidropônico. Pesquisa Agropecuária Brasileira, Brasília, v. 42, p. 289-292, 2007.

WONGA, Y. F; DAVIES, N. W.; CHIN, S. T.; LARKMAN, T.; MARRIOTT, P. J. Enantiomeric distribution of selected terpenes for authenticity assessment of Australian Melaleuca alternifolia oil. Industrial Crops and Products, v. 67, p. $475-483,2015$. 